\title{
PERFORMANCE ANALYSIS OF A DIESEL ENGINE WITHIN A MULTI- DIMENSIONAL FRAMEWORK
}

\author{
Hasan Koten ${ }^{a, *}$
}

\begin{abstract}
In this study, large-bore diesel engine combustion was modeled using development combustion model Extended Coherent Flame Models 3 Zones (ECFM-3Z). During this work, the study was made about an engine configuration with compression, spray injection, combustion and emission of the diesel engine. Prediction of incylinder combustion phenomenon, effects of turbulence levels, flow structures and emission modeling have an importance in designing efficient engines. Effects of in-cylinder flow structures, fuel injection and design parameters were investigated for the engine performance and emission results. The results agree broadly with experimental and computational studies. As a result, it is aimed to find out the flow structure, spray, combustion and emission characteristics of the large-bore diesel engine. In a precombustion chamber structure, it is seen that controlled combustion starts and then high-pressure gas mixture uniformly spreads into the main combustion chamber.
\end{abstract}

\section{Keywords: Diesel Engine, CFD, Emission, Performance}

\section{INTRODUCTION}

Internal combustion engines are widely used as the source of power in many fields. But, they have several disadvantages like difficult combustion control, high particulate matter, NOx emission, unburned hydrocarbons ( $\mathrm{HC}$ ) and carbon monoxide (CO) emissions. In the automotive industry, the new combustion processes which focus on clean diesel combustion are being investigated for minimum particulate and NOx emission potential. CFD methods are very useful tools to investigate the flow on complex and nonsymmetrical geometries generally for moving boundaries. Many studies were investigated using multidimensional modeling and obtained results are compared with the experimental results [1-7]. The significant feature of the diesel engine is the use of liquid fuels. The liquid fuel injected through the injector breaks up, atomizes and evaporates in a high temperature chamber and burns as being mixed with air. Cyril investigated that during the break-up, fuel spray, atomization and vaporization mainly depend on the air entrainment with a higher velocity and the higher temperature inside the engine cylinder [8]. Benajes et al. investigated the potential of the piston geometry to improve the results provided by the Reactivity Controlled Compression Ignition (RCCI) concept in terms of combustion efficiency and emissions [9]. Recently, CFD is gaining reliability in predicting emissions and combustion characteristics by using properly calibrated and validated models. Moreover, CFD modeling is a very efficient alternative method compared to the experimental approach especially for the optimization of the engine hardware due to its lower requirements in terms of time and resources. Thus, it is worth to develop an optimization methodology based on CFD modeling suitable for not only defining the optimum engine settings configuration, but also to identify the most relevant effects of the variables (inputs) to be optimized. Different researchers such as $\mathrm{Yu}$ and Strålin have been carried out using methods with really encouraging results related to optimum geometries [10-11].

In this study, it was aimed to simulate cold flow process appropriately in order to find the in-cylinder flow characteristics of single-cylinder, 5lt CI engine. Also injecting fuel, engine performance and emission were investigated. Fully intake, compression strokes as well as fuel injection at the end of the compression stroke and emission simulated in 3D. Both naturally aspirated and turbocharged operations have been studied. 5 liter singlecylinder diesel engine was modeled with the actual engine geometry, including the exhaust and intake manifold. In multidimensional modeling, simulations were expanded to obtain appropriate boundary conditions for valve lifts for intake and exhaust ports. The fine gratings were tested at 2.500.000. The fine grill results are presented on paper. Typical application time with thin cage for 720 CAD takes approximately 5 days on a 16-processor workstation running in parallel operation. As seen in the literature, the most general method for solving fluid 
flow is based on modeling Navier-Stokes equations. This methodology includes the continuity equation, the Navier-Stokes equations of momentum and the discretization of the energy equation to solve a specific fluid problem that is limited in space and divided into multiple computational cells [12-14]. Relevant equations continuity, momentum and energy equations were given below [12].

$$
\begin{gathered}
\frac{\partial}{\partial t}\left(\rho Y_{\alpha}\right)+\frac{\partial}{\partial x_{i}}\left(\rho Y_{\alpha} U_{i}\right)=\frac{\partial}{\partial x_{j}}\left(D \frac{Y_{\alpha}}{\partial x_{j}}\right)+\rho \dot{r}_{\alpha}+\dot{\rho}_{s} \\
\frac{\partial}{\partial t}\left(\rho U_{i}\right)+\frac{\partial}{\partial x_{j}}\left(\rho U_{i} U_{j}\right)=-\frac{\partial p}{\partial x_{i}}+\frac{\partial}{\partial x_{j}}\left\{\mu\left[\frac{\partial U_{i}}{\partial x_{j}}+\frac{\partial U_{j}}{\partial x_{i}}-\frac{2}{3} \frac{\partial U_{k}}{\partial x_{k}} \delta_{i j}\right]\right\} \\
\frac{\partial}{\partial \mathrm{t}}(\rho E)+\frac{\partial}{\partial x_{j}}\left(\rho E U_{j}\right)=\frac{\partial p}{\partial \mathrm{t}}+\frac{\partial}{\partial x_{j}}\left(\sigma_{i j} U_{j}\right)+\frac{\partial}{\partial x_{j}}\left(\lambda \frac{\partial T}{\partial x_{j}}\right)+\rho \dot{q}_{g}+\dot{Q}_{s}
\end{gathered}
$$

In cold flow studies, generally the simplest standard k- $\varepsilon$ model is widely used [15]. In spray modelling, there are numerous additional models for spray injection, spray breakup, droplet collision, evaporation, wall impingement etc [16, 17]. In atomization model, Huh's model was used as an atomization model in the simulations [18]. The break-up model of Reitz and Diwakar was also used to simulation of droplet break up [19]. O'Rourke model was used for collisions in the model. And also it was improved with a speed-up algorithm of Schmidt and Rutland [20,21]. Moreover, this model includes a coalescence timescale highlighted by Aamir and Watkins [22]. Bai's Spray impingement model was used in the simulations as a wall-interaction model for discrete phase. This model was formulated within the framework of the Lagrangian model, which is based on literature findings and mass, momentum and energy conservation constraints [23].

\section{COMPUTATIONAL GRID AND BOUNDARY CONDITIONS}

In combustion modelling, Wiebe function for 1D approximation and ECFM for 3D CFD solution are used [25]. It is simultaneously described in terms of mixing and progress of reaction as schematically represented in Figure 1. For emission simulation, the 3-step Zeldovich model was used for NOx and three options are provided for soot.

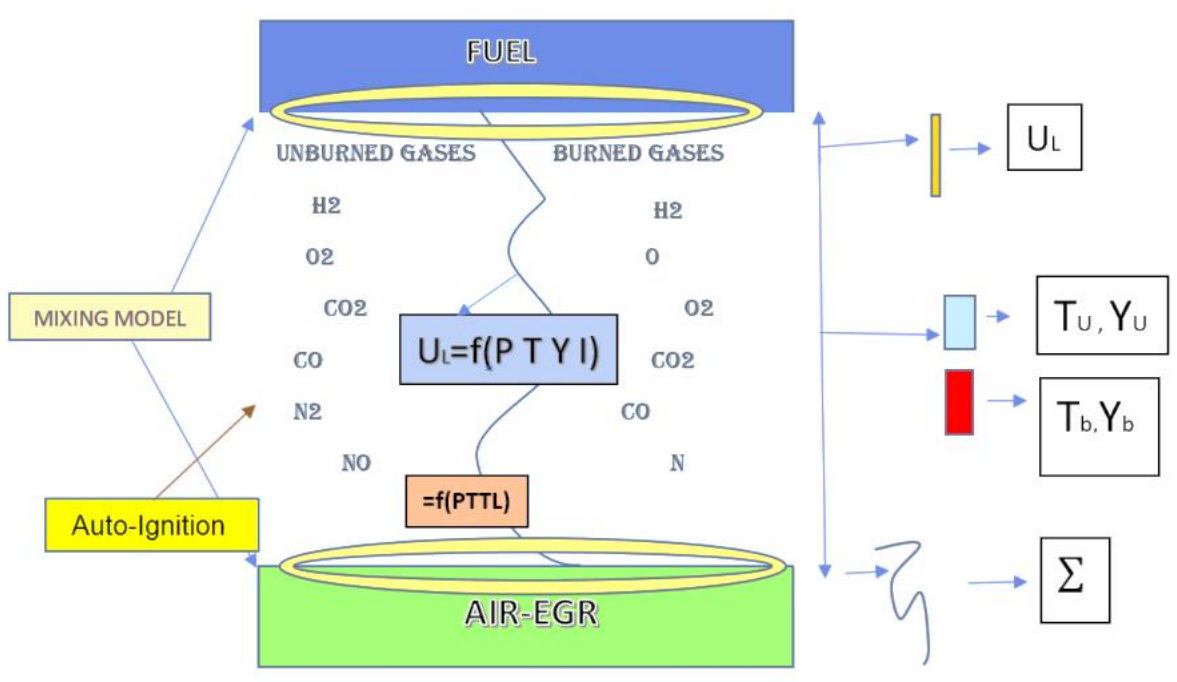

Figure 1. Schematic of the ECFM3Z model computational cell.

The engine modeled is a real single-cylinder 5lt heavy-duty diesel engine. The geometrical specifications of the engine, as well as the engine's original valve timings are summarized before chapter. The computational grid is shown in Figure 2. It consists of about 1.800 .000 cells at TDC. 


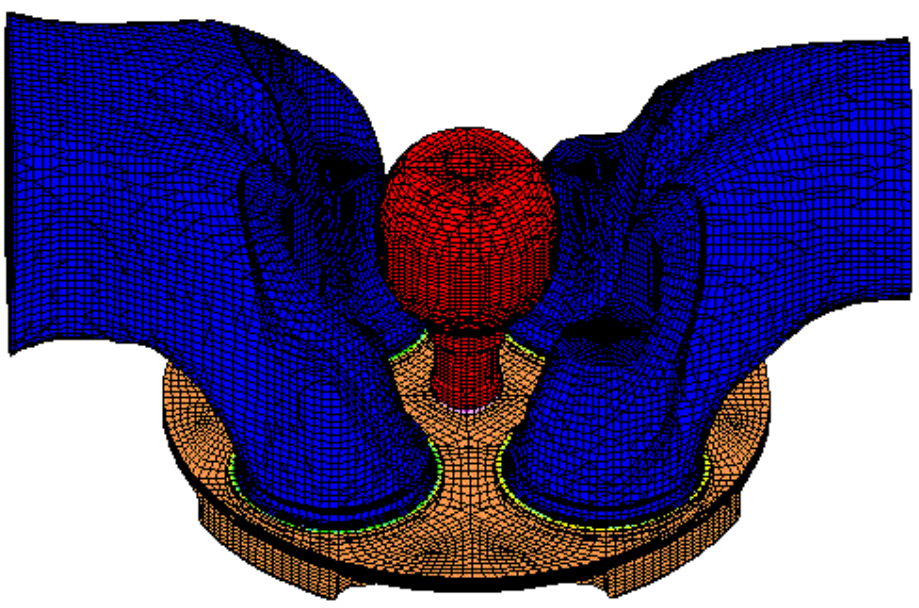

Figure 2. Engine mesh structure.

All the calculations were performed by means of the CFD code. The moving mesh (i.e. piston and intake valves regions) is provided by CFD code's tool designed to facilitate transient analyses of internal combustion engines. CFD solver pre-processor creates the fixed mesh (intake and exhaust ports). The computational grid is made up of cells of mainly hexahedral shape, whose number ranges from approximately 1.800.000 at TDC up to over 2.500.000 at BDC for fine mesh. In this study, single cylinder diesel engine was analysed and properties of engine was given in Table1. All the walls were treated with the turbulent law-of-thewall. The heat fluxes to the walls are calculated using constant temperatures near walls. The boundary condition at the inlet of the intake port is that of "pressure inflow", while that at the outlet of the exhaust port is "pressure outflow".

Table 1. Engine properties.

\begin{tabular}{lr}
\hline Bore / Stroke & 0.86 \\
Piston Pin Offset (mm) & 0.00 \\
Displacement/Cylinder (cc) & 5000 \\
Total Displacement (liter) & 1 \\
Number of Cylinders & 1 \\
Compression Ratio & 13 \\
\hline
\end{tabular}

\section{MULTIDIMENSIONAL MODELING}

Moving mesh feature was used to analyse the flow structure [26], combustion and emission inside the cylinder. The vector field shows less large structures and larger vortices can be seen Figure 3.

While piston goes from BDC to TDC, level of the swirl structure decreases during the end of the stroke. The velocity vectors during the compression stroke decreases due to friction causes less intensity on the flow structure. The maximum air flow velocity was obtained around the maximum valve lift. After maximum valve lift, velocity vectors gradually decrease during the intake stroke and compression stroke. Turbulence and air velocities generated purely during the compression stroke are much smaller than those generated during the intake stroke and can therefore be neglected [27]. Contours of the velocity were shown in Figure 4 to analyse parallel flow to the cylinder axis. It is seen in Figure 4 that about half of the maximum kinetic energy at TDC is increased as compared to the BDC when velocity magnitudes are considered. Velocity magnitude inside the cylinder was shown in Figure 5. This also will provide high kinetic energy levels. Several calculations for the flow in the engine cylinders have been previously carried out and established on the literature [27-35].

\section{RESULTS AND DISCUSSION}

1D engine code was used to simulate engine performance and exhaust emissions such as $\mathrm{CO}$ and NOx gases. The combustion pressure and in-cylinder temperature were evaluated under engine geometry conditions in 
order to verify 3D results. Wiebe function for 1D approximation and Extended Coherent Flame Model (ECFM) for 3D CFD solution were used to carry out the analysis of combustion. 3D engine code was used to find out flow structure in-cylinder and behaviour of the mixture combustion. Results reported in this section the engine operating conditions of $1000 \mathrm{rpm}$ and diesel fuel consumption with $14 \mathrm{~g} / \mathrm{kWh}$. In Figure 6 fuel injection and oxygen mass fraction were shown. The detailed operating conditions are listed in Table 2. Engine performance was given in Figure 7.

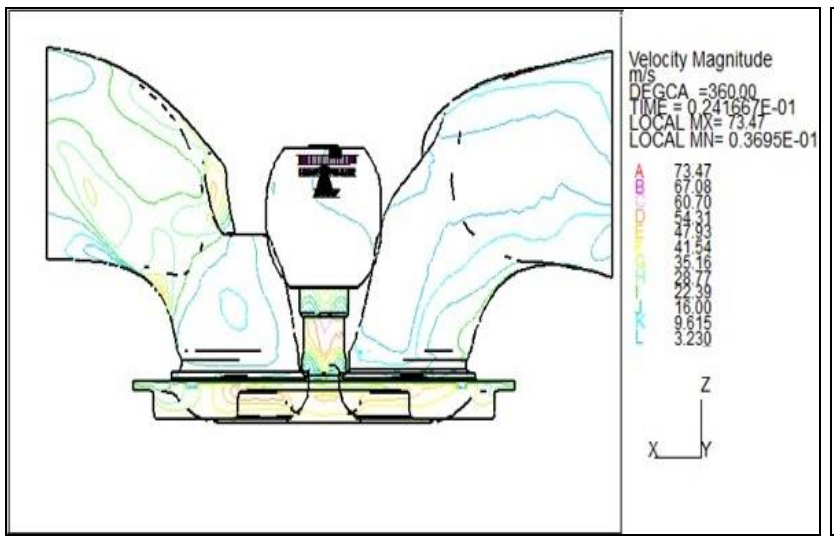

(a) $360 \mathrm{CAD}$

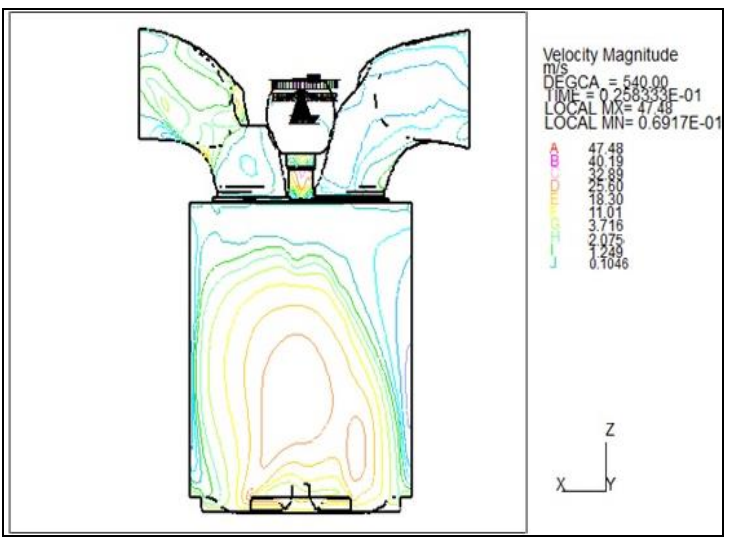

(b) $540 \mathrm{CAD}$

Figure 3. Velocity vectors in different views [26].
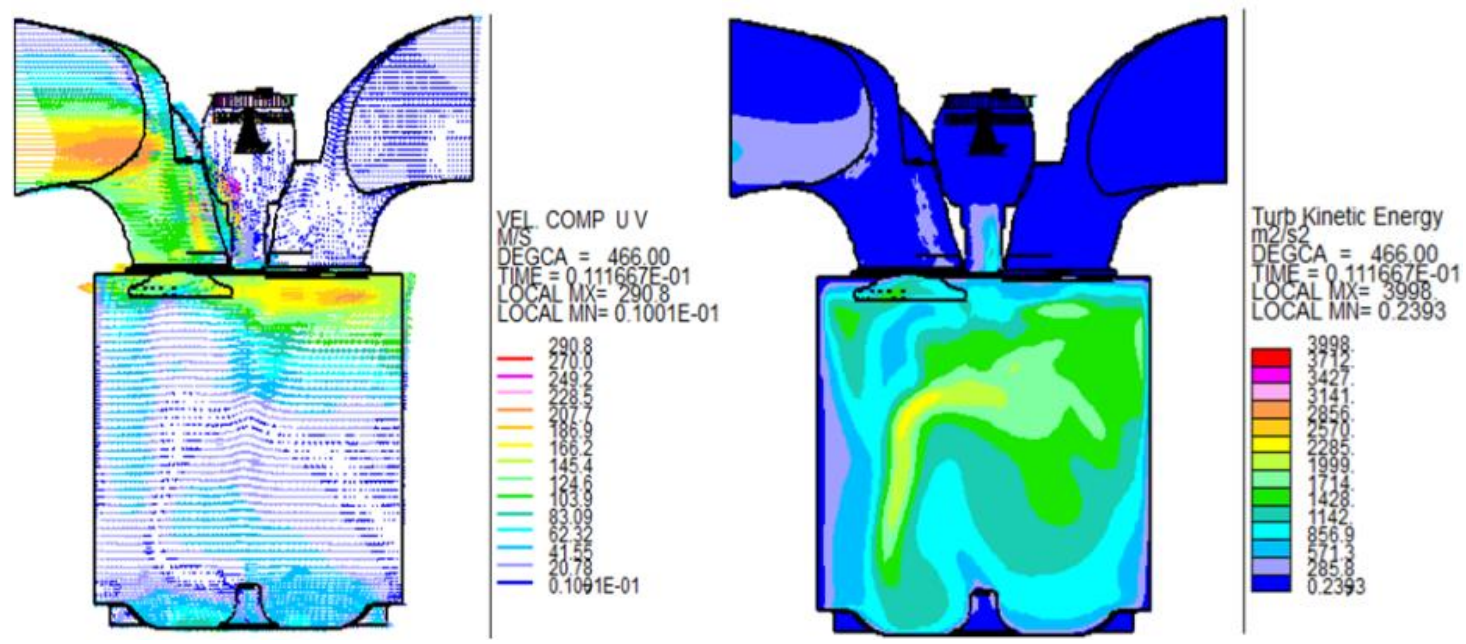

Figure 4. Contours of velocity and TKE at different crank angles during the compression stroke [26].

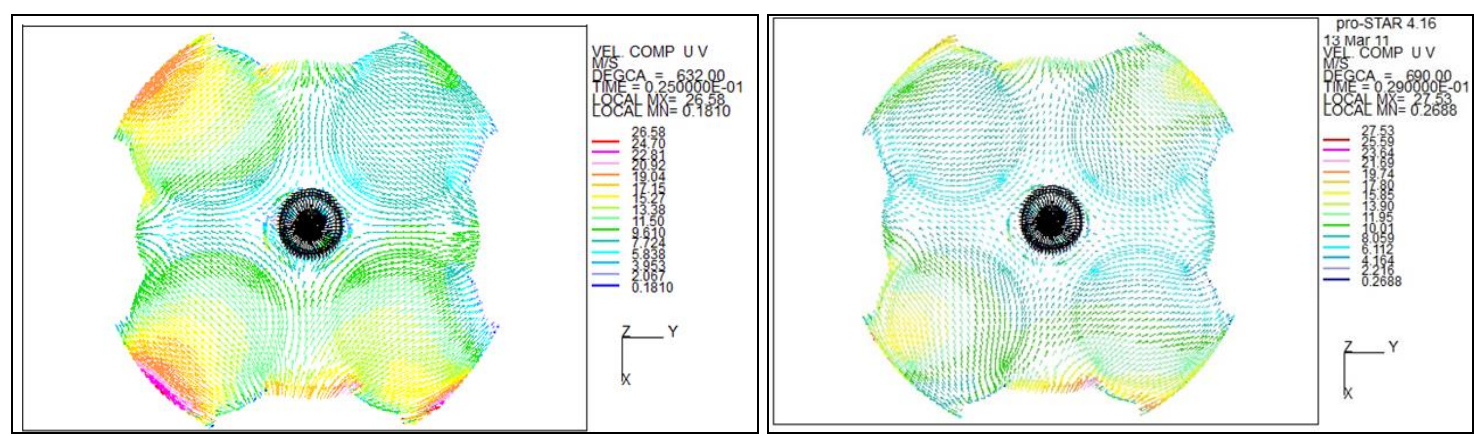

Figure 5. Velocity vectors at top view [26]. 
Journal of Thermal Engineering, Research Article, Vol. 4, No. 4, Special Issue 8, pp. 20752082, June, 2018

Table1. Operating conditions.

\begin{tabular}{ll}
\hline Engine speed & $1000 \mathrm{rpm}$ \\
Fuel consumption & $14 \mathrm{~g} / \mathrm{kWhr}$ \\
Intake pressure & $1.3 \mathrm{bar}$ \\
Intake temperature & $312 \mathrm{~K}$ \\
\hline
\end{tabular}

1D engine code was employed to validate 3D results as shown in Figure 6. 1D, 3D pressure value reached maximum value near TDC however, analysis reached a few degree crank angle later than engine codes. At the same time, 3D temperature results reached maximum value near TDC and 1D analysis yields a maximum about 19o CA aTDC. In Figure 8 NOx and CO emissions were given to investigate the combustion performance of the diesel engine.
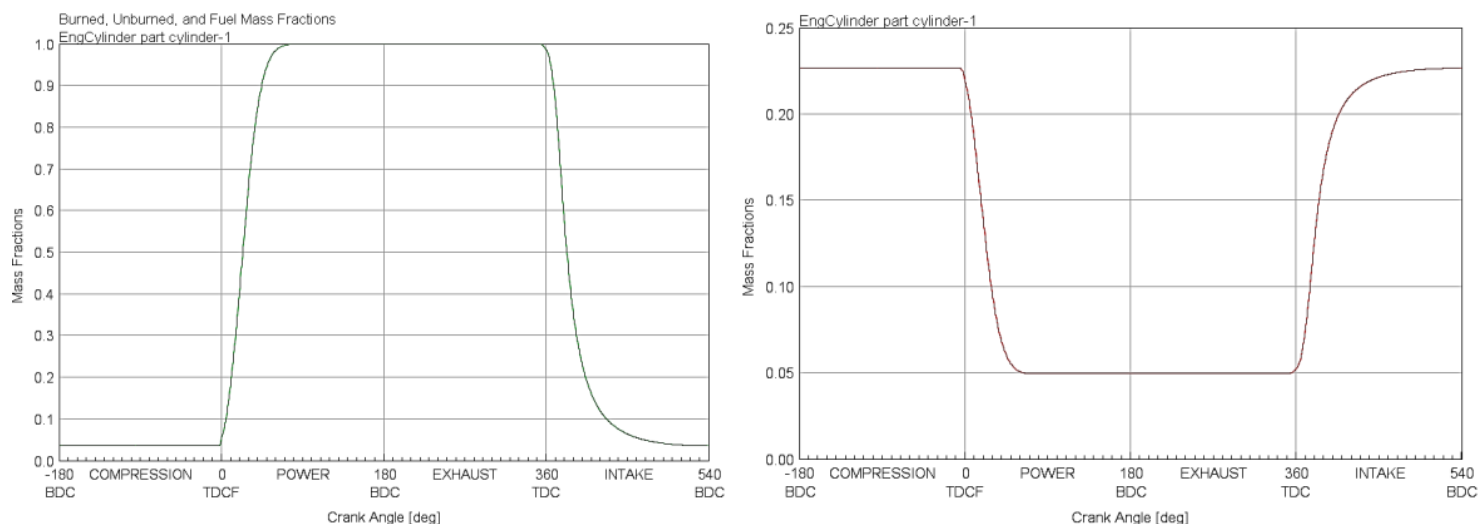

Figure 6. Diesel fuel and oxygen mass fractions.
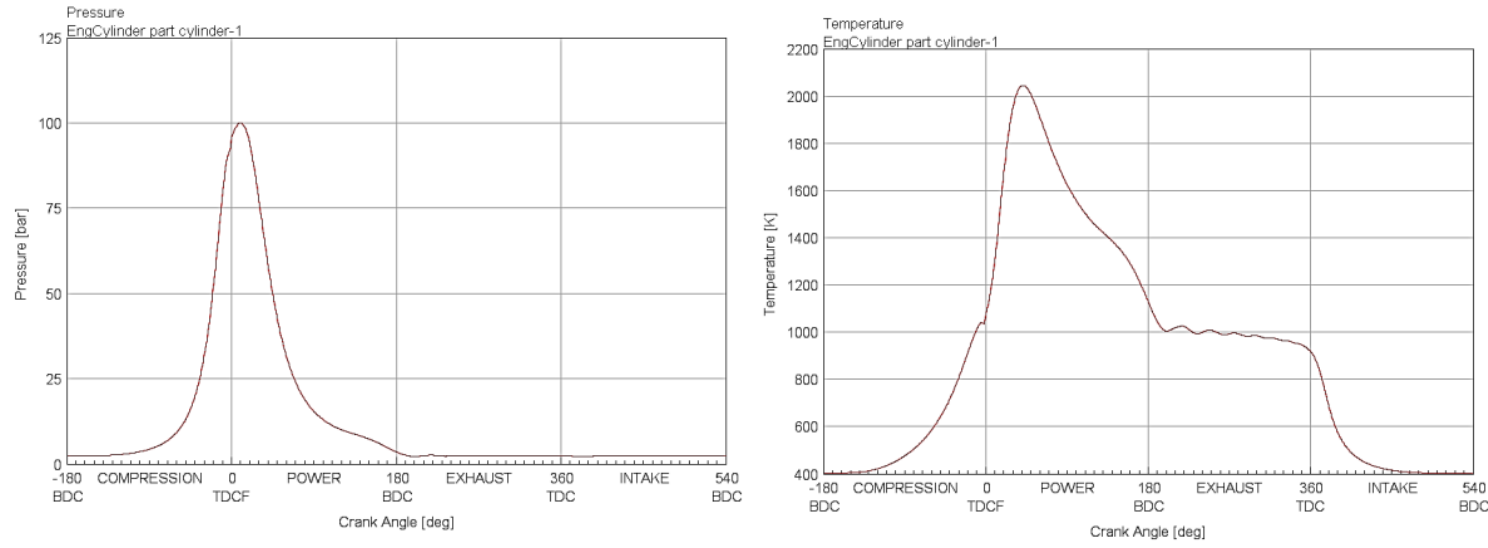

Figure 7. Engine in-cylinder pressure and temperature.
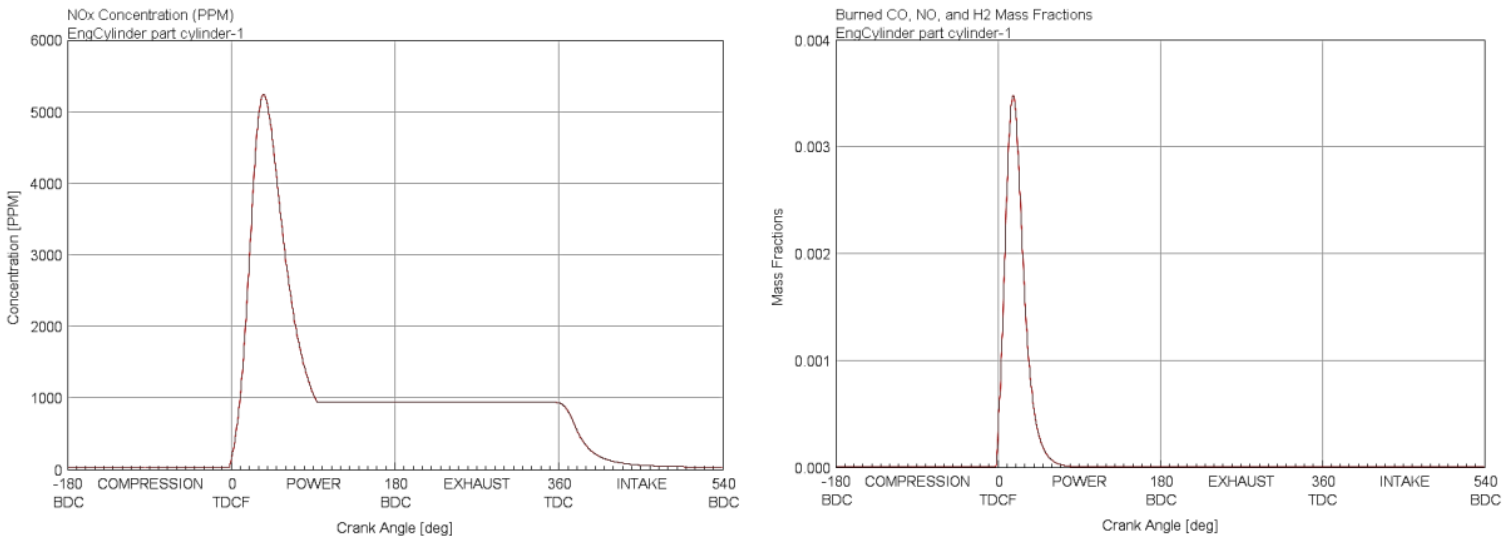

Figure 8. In-cylinder $\mathrm{CO}$ and $\mathrm{NOx}$ mass fraction results. 


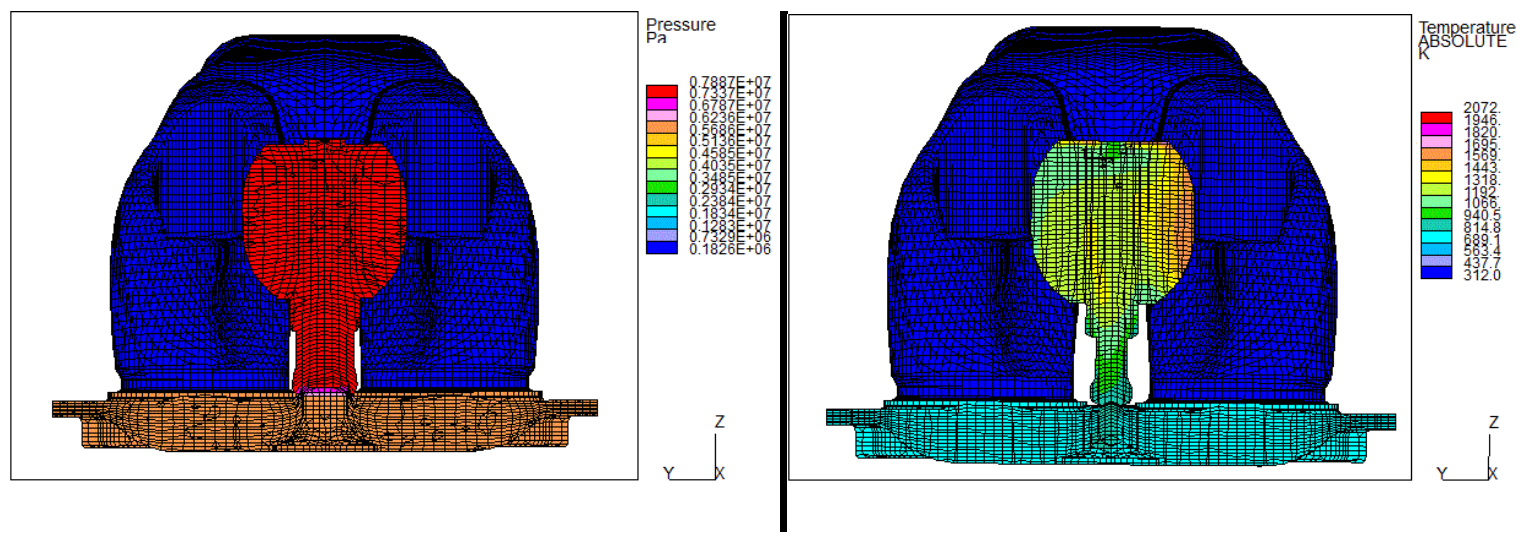

Figure 9. Pressure and temperature contours near TDC.

As seen in Figure 8, NOx concentration increases dramatically together with the ignition of diesel fuel. In this simulation, $\mathrm{NO}$ and $\mathrm{CO}$ mass fractions given in Figure 8 are formed in power stroke and disappeared to the BDC. In Figure 9, pressure and temperature contours with half geometry of combustion chamber (Z-axis) are given. High pressure and temperature inside the precombustion as shown in Figure 9 are resulted controlled combustion in the main chamber.

\section{CONCLUSIONS}

In this study, advanced combustion model ECFM-3Z [27-41] has been employed successfully to get more information about the in-cylinder physical events. In addition, calculation on an engine configuration with compression, spray injection, combustion and emission in a Diesel engine were accomplished. Effect of incylinder design parameters on cold flow structure and performance in a DI diesel engine were investigated and presented. It is seen that results are widely in agreement with previous studies in literature. Pressure and temperature distributions were also in the expected ranges according to validation results. 1D and 3D analyses results illustrated that turbulence is driven by combustion effect. 1D and 3D results have little difference due to dimensional differences. At the end of this study combustion and emission results were evaluated and compared for 1D and 3D calculations. According to combustion and emission results in Figure 8 and 9, NOx concentrations, pressure and temperature graphs were showed similar patterns expectedly. This precombustion chamber geometry is carefully modeled to provide adequate mixing of the fuel with the heated air. Increased pressure provides very good mixture of the air and fuel. The results show that the main combustion is achieved in the main cylinder. In addition, it is seen that the precombustion structure vaporized fuel droplets by means of high temperature and ensured controlled combustion and emission.

$\begin{array}{ll}\text { ABBREVIATIONS } \\ \text { aBDC } & \text { After bottom dead center } \\ \text { aTDC } & \text { After top dead center } \\ \text { BDC } & \text { Bottom Dead Center } \\ \text { BMEP } & \text { Brake Mean Effective Pressure } \\ \text { Bsfc } & \text { Brake specific fuel consumption }(\mathrm{g} / \mathrm{kWh}) \\ \text { CAD } & \text { Crank Angle Degree } \\ \text { CO } & \text { Carbon monoxide } \\ \text { CR } & \text { Compression Ratio } \\ \text { HCCI } & \text { Homogeneous Charge Compression Ignition } \\ \text { NOx } & \text { Oxides of nitrogen } \\ \text { PCCI } & \text { Premixed Charge Compression Ignition } \\ \text { PM } & \text { Particulate Matter } \\ \text { PPCI } & \text { Partially Premixed-Charge Compression Ignition } \\ \text { ROHR } & \text { Rate of Heat Release } \\ \text { SIMPLE } & \text { Semi-Implicit Method for Pressure-Linked Equations } \\ \text { SOC } & \text { Start of Combustion } \\ \text { SOI } & \text { Start of Injection } \\ \text { TDC } & \text { Top Dead Center } \\ \text { UHC } & \text { Total Unburned Hydro Carbon }\end{array}$




\section{REFERENCES}

[1] Payri F., Benajes J., Margot X., Gil A. (2003). CFD modeling of the in-cylinder flow indirect-injection diesel engines. Computational Fluids 33:995-1021.

[2] Vijayashree, Ganesan V. (2018). Application of CFD for Analysis and Design of IC Engines. In: Srivastava D., Agarwal A., Datta A., Maurya R. (eds) Advances in Internal Combustion Engine Research. Energy, Environment, and Sustainability.

[3] Jesus Benajes, et. al., (2016). Optimization of the combustion system of a medium duty direct injection diesel engine by combining CFD modeling with experimental validation, In Energy Conversion and Management, Volume 110, 212-229, ISSN 0196-8904.

[4] Amin M, Saray RK, Shafee S, Ghafouri J. (2013). Numerical study of combustion and emission characteristics of dual-fuel engines using 3D-CFD models coupled with chemical kinetics. Fuel 106:98-105.

[5] Choi S, Shin S, Lee J, Min K, Choi H. (2015). The effects of the combustion chamber geometry and a double-row nozzle on the diesel engine emissions. Proc Inst Mech Eng, Part D:J Automobile Eng; 229(5):590-8.

[6] Atmanli A, Yüksel B, Ileri E, Karaoglan AD. (2015). Response surface methodology based optimization of diesel-n-butanol-cotton oil ternary blend ratios to improve engine performance and exhaust emission characteristics. Energy Convers Manage; 90:383-94.

[7] Genzale, CL, Reitz RD, Musculus, MPB. (2008). Effects of piston bowl geometry on mixture development and late-injection low-temperature combustion in a heavy-duty diesel engine. SAE technical paper.

[8] Cyril C, (2002), Combustion process in diesel engine. Ph.D. thesis, University of Brighton.

[9] Benajes J, Pastor JV, García A, Monsalve-Serrano J. (2015). An experimental investigation on the influence of piston bowl geometry on RCCI performance and emissions in a heavy-duty engine. Energy Convers Manage; 103:1019-30.

[10] Park SW. (2010). Optimization of combustion chamber geometry for stoichiometric diesel combustion using a micro genetic algorithm. Fuel Process Technol; 91(11):1742-52.

[11] Yu Li, Hailin Li, Hongsheng Guo, Yongzhi Li, Mingfa Yao, (2017).A numerical investigation on methane combustion and emissions from a natural gas-diesel dual fuel engine using CFD model, In Applied Energy, Volume 205, 153-162, ISSN 0306-2619.

[12] Strålin, P., (2007). Lagrangian CFD Modeling of Impinging Diesel Sprays for DI HCCI, Royal Institute of Technology.

[13] Möller, C., (2006). 1-D Simulation of Turbocharged SI Engines - Focusing on a New Gas Exchange System and Knock Prediction, Royal Institute of Technology.

[14] Courant R. K. Lewy F. H.. (1928). Uber die Partiellen Differenzengleichungen der mathematischen Physik, volume 1.

[15] Wilcox, D.C. (1998). Turbulence Modeling for CFD. 2nd edition, DCW Industries, Inc.

[16] Gosman, A.D., Tsui, Y.Y., (1986), Flow in a Model Engine with a Shrounded Valve- A Combined Experimental and Computational Study. SAE Technical Paper Series, 850498.

[17] Davis, G.C., Mikulec, A., Kent, (1986). Modeling the Effect of Swirl on Turbulence Intensity and Burn Rate in S.I. Engines and Comparison with Experiment. SAE Technical Paper Series.

[18] Huh, K.Y., and Gosman, A.D. (1991). A phenomenological model of Diesel spray atomisation, Proc. Int. Conf. on Multiphase Flows (ICMF '91), Tsukuba, 24-27 September.

[19] Reitz, R.D., and Diwakar, R. (1986). Effect of drop breakup on fuel sprays, SAE Technical Paper Series 860469 .

[20] O'Rourke, P.J. (1981). Collective Drop Effects on Vaporising Liquid Sprays. PhD Thesis, University of Princeton.

[21] Schmidt, D.P., and Rutland, C.J. (2000). A new droplet collision algorithm, J. Comput. Phys., 164, 62-80.

[22] Aamir,M.A., andWatkins, A.P. (1999). Dense propane spray analysis with a modified collision model, ILASS-Europe'99, Toulouse, France, 5-7 July 1999.

[23] Bai, C., and Gosman, A.D. (1995). Development of methodology for spray impingement simulation, SAE Technical Paper Series 950283.

[24] Duclos, J.M., Zolver, M., Baritaud, T. (1999). 3D modelling of combustion for DI-SI engines. Oil \& Gas Science and Technology, Vol.54. 
[25] Colin O. and Benkenida A., (2004), The 3-Zones Extended Coherent Flame Model (ECFM3Z) for Computing Premixed/Diffusion Combustion, Oil \& Gas Sci. Tech., 59, 593-609.

[26] Ayaz E., (2017). Numerical Investigation of in-cylinder flow structure of TLM16V185 type heavy-duty CI engine, MSc Thesis, ITU.

[27] Song, Y.S., Hong, J.W. and Lee, J.T.. (2000). The turbulence measurement during the intake and compression process for high-turbulence generation around spark timing, Proceedings of the Institution of Mechanical Engineers, Part D: Journal of Automobile Engineering, vol. 215, 493-501.

[28] Zur Loye, S. O., Siebers D. L., Mckinley T. L., Ng H. K. and Primus R. J., (1989). Cycle-resolved LDV measurements in a motored Diesel engine and comparison with k- epsilon model predictions, SAE Paper 890618.

[29] Kono, S., Terashita, T. T. and Kudo, H., (1999). Study of the swirl effects on spray formation in DI engines by 3D numerical calculations", SAE Paper 910264.

[30] Chen, Y.S., and Kim, S.W. (1987), 'Computation of turbulent flows using an extended k- $\varepsilon$ turbulence closure model, NASA CR-179204.

[31] Launder, B.E., and Spalding, D.B. (1974). The numerical computation of turbulent flows, Comp. Meth. in Appl. Mech. and Eng., 3, 269-289.

[32] Morel, T. and Mansour, N. N., (1982). Modeling of Turbulence in Internal Combustion Engines, SAE Technical Paper Series, 820040, International Congress and Exposition, Detroit, Mich., February 22-26, 1982.

[33] Speziale, C. G. (1987). On nonlinear k-1 and k- $\varepsilon$ models of turbulence, J. Fluid Mech., 178, 459-475.

[34] Versteeg HK, Malalasekera W, (1995). An Introduction to Computational Fluid Dynamics - The Finite Volume Method, Longman Group Ltd. London, United Kingdom.

[35] Yakhot, V., and Orszag, S.A. (1986). Renormalization group analysis of turbulence-I: Basic theory, J. Scientific Computing, 1, 1-51.

[36] Shi, X., Li, G., and Zhou, L., (2007). DI Diesel Engine Combustion Modeling Based on ECFM-3Z Model, SAE Technical Paper 2007-01-4138.

[37] Priesching, P., Ramusch, G., Ruetz, J., and Tatschl, R., (2007). 3D-CFD Modeling of Conventional and Alternative Diesel Combustion and Pollutant Formation - A Validation Study, SAE Technical Paper 2007-011907.

[38] Fonseca, L., Braga, R., Morais, L., Huebner, R. et al., (2016). Tuning the Parameters of ECFM-3Z Combustion Model for CFD 3D Simulation of a Two Valve Engine fueled with Ethanol, SAE Technical Paper 2016-36-0383.

[39] Mohamed Morsy, Andi Sudarma (2017). RANS Numerical Simulation of Lean Premixed Bluff Body Stabilized Combustor: Comparison of Turbulence Models, Journal of Thermal Engineering, 2017, Volume: 3, Issue: $6,1561-1573$.

[40] G. Najafi, (2018). Diesel engine combustion characteristics using nano-particles in biodiesel-diesel blends, Fuel, Volume 212, 668-678, ISSN 0016-2361.

[41] Raouf Mobasheri, Mahdi Seddiq, Zhijun Peng, (2018). Separate and combined effects of hydrogen and nitrogen additions on diesel engine combustion, International Journal of Hydrogen Energy, Volume 43, Issue 3, 1875-1893, ISSN 0360-3199. 